Article

\title{
Peace with Hunger: Colombia's Checkered Experience with Post-Conflict Sustainable Community Development in Emerald-Mining Regions
}

\author{
Isabel B. Franco ${ }^{1,2, *}$, Jose A. Puppim de Oliveira ${ }^{3}$ and Saleem H. Ali A $^{2,4}$ (D) \\ 1 Institute for the Advance Study of Sustainability, United Nations University, 5 Chome-53-70 Jingumae, \\ Shibuya, Tokyo 150-8925, Japan \\ 2 Sustainable Minerals Institute, The University of Queensland, St Lucia Campus, \\ Brisbane, QLD 4000, Australia \\ 3 Getulio Fundacao Getulio Vargas, Praia de Botafogo, 190-Edificio Luiz Lopes (Sede), Botafogo, \\ Rio de Janeiro-RJ 22250-900, Brazil; japo3@yahoo.com \\ 4 University of Delaware, Pearson Hall, Newark, DE 19716, USA \\ * Correspondence: franco@unu.edu or isabel@drisabelfranco.com (I.B.F.); \\ s.ali3@uq.edu.au or saleem@alum.mit.edu (S.H.A.)
}

Received: 29 December 2017; Accepted: 6 February 2018; Published: 13 February 2018

\begin{abstract}
The interactions between conflict and local development has puzzled scholars and practitioners alike. This article explores why the advent of peace in Colombia's emerald-mining regions for the past few years, as well as a broader national peace process, has not delivered the expected development dividends among mining communities. We contrast differences in stakeholders' perceptions between levels of governance (local, regional and national). Based on the research, we conclude that while stakeholder collaboration is successful at the regional and national levels of governance, it fails at the local level. While peace has allowed an increase in mainstream business investment in mining, this has concentrated production in a few hands leading to a deterioration in many aspects of community livelihoods and wealth distribution. There has been a shift in the concentration of wealth and production from traditional elites to large companies. Communities noted a loss of collective assets and lack of community and institutional capacity to overcome pressing issues in a post-conflict market economy that favors those who control capital and technology. Based on an evaluation of community perceptions through a focus group methodology, this study recommends ways to prepare and better coordinate stakeholders to engage with complex relationships, and protect community assets in a collaborative governance scenario. This research suggests that political reconciliation processes amid complex resource geographies require greater devolution and community engagement on post-conflict economic development during the peace process itself.
\end{abstract}

Keywords: artisanal mining; emerald mining; governance; postconflict; sustainable community development; Colombia

\section{Introduction}

"I was told by a senior executive in the mining emerald industry they had spent many millions of dollars, so that well-known princesses, princes and famous top models could wear a luxurious necklace. You are speaking in a different language-I said. Thank you for letting me know this but my heart cries for those single mothers in Muzo who cannot afford food for their children. All that 
money you are talking about is being spent abroad. We have not got a coin from that luxurious necklace" [1].

While the FARC (Spanish: Fuerzas Armadas Revolucionarias de Colombia-FARC) was signing the peace agreement in Colombia in May 2017, the research team prepared its trip to Muzo, better known as "the emerald capital of the world". The Revolutionary Armed Forces of Colombia is a guerilla group with a Marxist ideology founded in 1964 that used to control vast areas of the country and perpetuated kidnappings and bomb attacks before the peace agreement with the government. The FARC was particularly active in resource-rich regions of the country.

Even though the FARC was not active in Muzo, "the emerald capital of the world" was one of the hardest-hit towns by violence in Colombia during the leadership of Don Victor Carranza, the major emerald dealer and the owner of the largest emerald mines in the region. In the past three decades until the death of Victor Carranza in 2013, nearly 3000 people died in Muzo due to conflict. His death led to a restructuring of emerald mining and to a sharp decline in violence. However, "there is peace with hunger": this was the consistent message we got from local mining communities during our stay in Muzo. This surprised the team as peace is perceived to be the cornerstone of sustainability, particularly in mining. We expected that the long-awaited peace in Muzo would bring prosperity and sustainable community development, but instead peace led to a formalization of mining activities concentrated in the hands of large mining groups and almost a halt in artisanal mining, which was the source of income of a large part of the population.

The interactions between conflict and local development have puzzled scholars and practitioners alike. The notion that peace and non-conflictual relations among stakeholders lead to progress seems intuitive. Many assume the "governance orthodoxy": the notion that stakeholders in a governance collaborative scenario interact through mutually agreed consensus and equally shared responsibilities [2]. However, in this manuscript it is argued that peace and collaborative processes do not necessarily lead to better outcomes to all local stakeholders. Peace processes change the local political economy and generate different paths of local development, which may not always benefit local communities in all aspects, as local development outcomes are affected by broader development processes led by non-local political and economic forces.

Based on a case study methodology, this study explores how stakeholders' collaboration, their expertise and resources, despite dissimilar perceptions, can become the drivers to achieve sustainable community development in emerald mining regions. This research also aims to understand the relations between conflicts and community development and implications for economic sustainability, using the case of emerald mining in Colombia. In Muzo, the peace after the death of Don Victor Carranza in 2013 led to the arrival and consolidation of the operations of an American mining company. Peace was then guaranteed locally by private security and nationally by the Colombian government signing of the peace agreement with the FARC guerrilla groups. Interestingly, while global organizations fight hunger with peace [3]; at the local level, at least in Muzo, "peace fights with hunger" [1]. This phrase seemed awkward to the research team initially-perhaps lost in translation-as it suggested an endogenous relationship between peace and economic deprivation. Researchers were intrigued as they expected a thriving community with the opportunities of having peace now and huge wealth that could be brought by emeralds. Through fieldwork the research team ascertained from further analysis of respondents' statements that in essence communities felt that peace processes were often in conflict with local economic opportunities. The communities were not talking about a war economy that may at times lead to community benefits [4,5]. Rather, they were implying that peace brought with it dominant market players who decreased community access to mineral rents and increased inequality.

During conflict, guerrilla groups, specifically FARC, pressured local administrations through coercion and corruption to inflate social investment and infrastructure contracts coming from mining revenues. These practices were undertaken in exchange for a safe environment and for potential electoral backing for politicians who sympathized with the guerrillas [6]. Communities in mining 
regions were the first victims of the disputes between legal and illegal actors over mining revenues. Conflict intensified along with guerrilla interest in tapping into mining royalties. As this situation became unsustainable, the current administration under President Santos began a negotiation process that led to the peace agreement with FARC in May 2017. The post-conflict leverage of the potential of local communities is expected, particularly those residing in mining regions.

Global demand for gemstones and the need to foster sustainable community development in Muzo have posited new responsibilities on stakeholders (governments, private sector and civil society) in the Colombian emerald industry. This situation, along with the loss of artisanal mining as a livelihood option, is creating tensions at the local level of governance. Locals complained of the loss of small-scale mining as a subsistence livelihood option, and also a lack of job opportunities in larger mining operations due to scale and automation. The research here documents community perceptions and contrasts them with stakeholders' views at all levels of governance, namely local, regional and national. This investigation also aims to draw recommendations for stakeholder engagement in peace processes elsewhere, so that they can forge collaborative governance arrangements for sustainable community development and hopefully can fight hunger with peace.

Colombia is a country with great potential of natural resource development. Oil has been one of the primary industries for decades. However, due to conflict-based factors, the mining sector has not developed at the same pace as the oil industry. Large reserves of minerals are located in remote areas that were difficult to access due to the presence of illegal groups over past decades [7]. With the signing of the peace agreement, stakeholders in the mining sector expect to unleash the geological potential of the country. However, questions about sustainability of artisanal mining and provision of alternative livelihood options remain relevant for locals. These factors have not only hampered the sustainable use of natural resources, but have compromised sustainable community development, particularly in the context of resource-rich regions. Stakeholders also expect that after the signing of peace in Colombia, the mining industry would engage in collaborative governance arrangements aimed to promote lasting community development.

In this context, this manuscript seeks to examine communities' and stakeholders' perceptions in alignment with the existing governance framework. This will help identify community assets and priority areas for sustainable community development valuable for locals. It also draws recommendations to assist stakeholders in addressing existing global resource consumption challenges. Supported by desktop research, and policy and focus group discussions with relevant stakeholders, this manuscript analyzes the challenges for a sustainable agenda for sustainable artisanal mining in Muzo, Colombia. The findings focused on the emerald sector. However, the findings and recommendations can also be applied to other sectors in the mining industry in Colombia and elsewhere. In particular, we consider how international perceptions of "peace" at a national level in a country such as Colombia might not reap development dividends without a concomitant commitment to local livelihood dynamics.

This study provides two major contributions to the debates about the links between peace and development. Firstly, it is argued that peace processes are not beneficial to all dimensions of local development. Although peace processes may increase local security, they unleash other political and economic forces, which may concentrate wealth and power, if appropriate governance mechanisms are not in place. Secondly, we show that there are major differences between stakeholders' perceptions at the local and national levels. This helps us to understand the distinct, and sometimes conflicting, interests and challenges for governance processes at different scales.

The manuscript continues with a literature review on governance for sustainable community development followed by the methodology and research findings based on field work and an analysis section that accounts for existing community assets and priority areas to drive sustainable community development in the emerald mining sector at the local and national governance levels. The manuscript finishes by presenting the discussions of the findings in the face of the literature and proposes a governance approach to sustainable community development. Conclusions and recommendations 
for stakeholder management in regions undergoing peace processes are presented at the end of this manuscript.

\section{Governance and Sustainable Community Development}

The assumption that stakeholders in a governance collaborative scenario interact through mutually agreed consensus and equally shared responsibilities is what Davies [2] called the "governance orthodoxy". Davies expresses his concern about this approach, arguing that both conflict and collaboration arise in governance arrangements. In the governance orthodoxy approach relationships among stakeholders are "captured in the common use of the terms partnerships or collaborative networks" [8]. Many scholars in the corporate social responsibility arena seem to follow this orthodoxy [9]. It is argued that the synergy among different actors results in positive effects on communities since these interrelationships build sustainable outcomes for locals [10,11]. For example, Warhurst's work [11] claims that in the Colombian context, partnerships in mining enabled the access to public services and led to sustainable outcomes at the local level. The governance orthodoxy approach very often can be found in the international agenda governance arrangements. In an international setting, this approach positions partnerships as a collaborative approach to pursuing goals in developing countries [6].

In sectors such as mining, international agencies that "govern" the mining corporate sector are becoming supporters of this approach and encourage corporations to engage in partnerships with governments and non-governmental organizations to ensure the delivery of sustainable initiatives at the local level $[12,13]$. However, to what extent this collaboration is equitable and power balanced? Mining corporations have adopted this governance approach in their social responsibility and sustainability agendas [14]. However, at the local level, corporations have encountered a major barrier when implementing this approach [15]. Corporate and government engagement with artisanal miners is very often challenging and therefore overlooked, or on the other hand being left out of conflict resolution processes in mining [13]. Instead of engaging with mining communities, public and private stakeholders at the international and national levels of governance tend to task artisanal miners with national and international regulations and standards that go beyond artisanal miners' capacity. In the Colombian context, artisanal miners who do not abide to international and national expectations are often left out of prime markets by "fair-trade" initiatives, or sometimes seen as criminals and, in worse cases, have been persecuted [13].

The interactions among stakeholders very often lead to negotiations of multiple interests, resources, responsibilities and degrees of influence, leading to conflict as well as collaboration [8]. "Collaboration is not an ideal solution in all cases and potential benefit will only be realized if the collaborative grouping has appropriate brokering, coordination and leadership, overcomes challenges and avoids potential pitfalls associated with forming and maintaining networks" [16]. In mining regions, the interactions among stakeholders such as corporations, artisanal mining communities, governments and education institutions have elicited collaborative as well as conflict-laden relationships among actors [6]. These both foster and limit the possibilities of sustainable community development.

If fostering and hampering factors are identified at early stages of collaborative governance processes, it can assist stakeholders in achieving international development standards and therefore lasting community development [17]. Understanding the local community's perceptions is the starting point from which to identify issues [18] and strong commitment and leadership from various stakeholders are also necessary for this to happen. Local stakeholders in isolation are not able to guarantee lasting community development valuable for local communities. Wang et al. [15] identified existing limitations in a governance scenario. Many issues not related to violent conflicts are left out of peace processes, such as inequality and fair access to mineral resources. The authors agree that despite existing community engagement and collaboration among stakeholders many issues that need to be tackled may not be adequately addressed individually. Hence, actors involved at different levels are 
encouraged to embrace equal participation and responsibilities in the implementation of actions aimed to promote sustainable community development. Acknowledging hampering and fostering factors will assist stakeholders in impacting communities in a positive meaningful way [19].

Governance arrangements that acknowledge differences among stakeholders can better unleash the potential of community support and therefore increase the possibilities for companies to gain and maintain a social license to operate in the expansion of mining operations [11]. For artisanal miners this approach can assist them in engaging with other stakeholders to leverage resources and foster sustainable outcomes for themselves, companies and other stakeholders involved. Therefore, it is important that companies, mining communities, national and local governments and other relevant stakeholders in the mining sector take part in governance for sustainable community development that can create shared value, hopefully for all parties. Certainly, this involves important challenges in the practicality due to the complexity among stakeholders' relationships. However, in spite of the difficulties that this approach might experience in practice, empirical research has shown the potential of embracing conflict as part of governance agendas in resource contexts [6,20].

While global norms, corporations often posit a top-down approach to sustainable community development, while other approaches to corporate social responsibility and sustainable development position as a bottom-up approach to assist communities to improve their living conditions [9]. Analysts have discussed the most destructive aspects of a top-down or corporate-centered approach to governance, particularly those related to social and environmental domains [14,21]. Most importantly, sustainable community development is considered a sustainable legacy for communities, which is critical to their livelihoods $[22,23]$. In the literature it is also stated that sustainable community development cannot rely on communities alone, since they often lack education and capacities to communicate their aspirations and become active participants in their own development [19,24,25]. However, governance arrangements that foment the synergy and cooperation among local actors can overcome some of the barriers to innovate towards sustainable solutions for small mining [26,27]. In those cases in which the conditions of local communities prevent them from engaging in collaborative governance for sustainable community development, government, civil society, education institutions and even large companies in the mining chain or locally based might assist them in overcoming these obstacles. Therefore, a key aspect of fair governance for sustainable community development is to not bypass the participation of other stakeholders such as governments [20] and local communities. In this context, it is important to explore the collaboration of stakeholders in the emerald-mining sector and the way in which their expertise, resources and divergent perceptions can become the drivers to achieve sustainable community development in emerald mining regions.

\section{Case Study Selection and Methodology}

Colombia, and the Muzo region in particular, was selected as a case study as the country has experienced mining growth over recent years, while also grappling with conflict resolution processes across a variety of ongoing insurgencies and civil strife within its borders. Muzo offers the opportunity to study the impacts of a peace process on local development through the exploitation of natural resources (mining). The region is known as a leading exporter of emeralds [28,29]. Some of the best and most valuable emeralds in the world have come from there. Emerald mining has taken place in Muzo since before the Spanish arrived. The emerald-mining industry operates across the country and can be classified in terms of the participation of mining and exploration companies in the domestic and the global market. The sector consists of various segments, artisanal mining and small-scale mining (ASM) being one of the most representative [1]. However, emerald mining very often does not translate into positive long-term benefits for the local population, particularly for artisanal miners and overall mining communities. This can create a series of social and environmental problems triggered by poor mining practices and loss of livelihood options. Hence, this manuscript also aims to identify current trends in artisanal emerald mining and adds value to the emerald-mining sector in Colombia by unveiling the potential of artisanal mining communities for sustainable community development. 
It is also aimed at identifying various constraints and opportunities that either hamper or foster the provision of sustainable development outcomes where the emerald mining sector operates.

The methodology chosen for this research was case study, as it allowed understanding of a phenomenon (peace process in a mining region) through in-depth analysis of the causalities and impacts [30]. Quantitative and qualitative information about Muzo, particularly information related to emerald production, was between January and August 2017. Data was initially gathered from background research [6], literature review, policy and document analysis and websites about emerald-mining activities in Muzo, Colombia, and worldwide trade. Data analysis of secondary sources helped us identified areas for further research. Once areas were identified and research design was in place, the research team embarked on field visits. Fieldwork was then conducted in May 2017 to do field visits and interviews with various sites and stakeholders in Bogota and Muzo, as well as during the participation of the National Mining Congress of Colombia in Cartagena, where the research team had semi-structured interviews with 16 stakeholders working in the emerald sector. Individual interviews helped the team to better understand the context and governance environment of the emerald mining industry in the Colombian case. Informal interviews were also conducted with several miners, citizens and small businesses. Interviews addressed three main components: the context in which local communities are embedded; existing complexities in governance dynamics and priority areas for sustainable community development. Additional comments were also provided by participants at all levels of governance. In those cases in which participants could not join formal group interviews and focus groups they engaged through informal conversations that helped the research team to better understand the subject of inquiry.

Finally, two workshops were organized, one in Muzo and one in Bogota, to identify the strengths, weaknesses, opportunities and threats of emerald sector. The workshops were divided into four parts, in which the participants made strong contributions identifying the strengths, weaknesses, opportunities and threats (SWOT) of the emerald sector for the local development of the Muzo region. The SWOT analysis was conducted during the workshops in order to organize the dynamics of the workshop to identify priority areas valuable for sustainable community development. This could guide stakeholders at all levels of governance to move forward to achieve overall sustainability. Weaknesses or threats were also identified as priority areas for local communities as well as domains that need major attention by all stakeholders involved.

In the Muzo workshop, the 12 participants were local stakeholders, such as members representing the small miners associations (Asociaciones de Barequeros), a large mining company, the city council, city hall, local emerald traders and independent miners. The workshop in Bogota had 15 participants, including officials from the ministry of mines, academics (researchers from universities of Los Andes, UPTC and National University of Colombia in Medellin), presidents of jewelry trading associations, NGO staff and the director of a large mining company.

\section{Results and Discussion}

From a theoretical standpoint, effective multi-stakeholder collaboration is a key driver in establishing sustainable community development in resource locations. However, in practice there are factors that can either limit or foster those processes. Based on recent governance debates and stakeholders' perceptions at all levels of governance, this section discusses and presents stakeholders' perceptions identified as high-priority areas for sustainable community development. This study also introduces a governance approach for sustainable community development to be applied to resource regions in Colombia or somewhere else.

The assumptions underpinning the notion of the governance orthodoxy are challenged by scholars who highlight the possibilities of conflict in governance processes [2,6,8]. Davies [2] argues that conflict arises due to the complexity of power relations and the context in which they are embedded. When this happens, the exercise of the authority is necessary to sustain them. However, this authority can either foster or undermine the trust among networks in peace processes, as well as make changes in 
the local political economy. Following Davies [2], Minnery [8] and Franco [6], this research recognized the possibilities of existing both collaboration and conflict at all levels of governance and the need for both options to be examined in order to have a more balanced negotiation of the development processes catalyzed by the political and economic changes coming with peace. Governance includes but transcends government; that is, governance involves diverse actors, each of them with different interests and capable of influencing policy agendas in particular ways, but can also create conflicts if there are no mechanisms to solve the differences in stakeholders' interests [31].

Our research found that in theory the government can be a more active player to steer local development processes in times of peace, whereas in practice there is a significant government absence at the local level without governance structures to make governments accountable [1]. The conflictual relations may put pressure on decision-makers to deliver better development outcomes and opportunities, such as mining rights, including access to mines and local share of the royalties, to all local stakeholders.

This research also explored the different conflict-collaboration dynamics during focus group discussions with local communities and national decision-makers. We analyzed the synergies and differences between local and national governance levels according to stakeholders' perceptions. Our research showed that there are significant discrepancies between perceptions and priorities between levels of governance. For example, while stakeholders at the national level think nationalizing royalties may reduce corruption at the local levels, local stakeholders perceive royalty nationalization as improper appropriations of local resources, leaving locals with problems and outsiders with the control of resources and decision-making power. Thus, peace processes should also understand better the differences between governance dynamics at various levels in order to avoid skewed distribution of resources between actors at the different governance levels during peace processes.

Due to global consumption demands, stakeholders at all levels of governance struggle to find ways to provide artisanal mining communities with sustainable options [6,22,32]. Based on the Colombian Constitution, the country should engage in addressing global-local demands to achieve overall sustainability in an emerging mining environment [33]. Findings in the focus group in Muzo showed that collaborative governance arrangements had the potential to contribute to sustainable community development, but failed to materialize after the peace process. National resource-based economies are more often encouraged to develop collaborative governance systems designed to meet global resource demands in a sustainable and responsible manner, but that may not lead to benefits in all local development dimensions.

\subsection{Contrasting Stakeholders' Perceptions at All Levels of Governance}

Complexities in collaborative governance compromise stakeholders' efforts to foster sustainable community development. Issues associated with gaps between corporate agendas and local community development aspirations, weak governance at the local level, informal mining and conflict are some of the factors that limit multi-stakeholder collaboration for lasting community development. Nevertheless, more effective governance arrangements among stakeholders (communities, companies and governments) need to take place to overcome existing barriers and fostering sustainable community development. This section contrasts stakeholders' perceptions at all level of governance about high-priority areas to enhance community assets and foster sustainable community development.

\subsection{Perceptions at the Local Level of Governance}

"Peace with hunger" was a persistent message at the focus group discussion with local communities. Unrest, discomfort and tensions among participants were evident. "Barequeros", the local name for artisanal emerald miners, were actively involved in the discussion. Mining associations' members, merchants, town council members, community and women's leaders were also actively involved. The beginning of the workshop was characterized by a dense environment. 
The dialogue had not yet started when participants engaged in a vibrant debate about the absence of employment, education and entrepreneurship opportunities for locals.

"When I first started the 'guaqueo', or informal mining, I used to exchange emeralds for groceries. Over the time, I was able to get some money that helped me pay my children's education. Nowadays, there is no artisanal mining. Unfortunately, the government think we all are criminals. There are policies in place but those only applied to multinational companies. We were told we were not allowed to mine. We will be persecuted if we continue undertaking artisanal mining activities on informal basis. We need to have money to be able to mine. This is a very complex issue and we are witnessing the beginning of a huge social problem that will exacerbate in the coming years. Due to the loss of mining as a livelihood option, people are embarking on criminal activities. They do not have any other option. What do you do when you have no job and you are starving? You engage in illegal activities, right? If we do not diversify the economy, if we do not educate people, if we do not build capacity in other areas different from mining such as entrepreneurship, we will start witnessing the rising of the worse criminals in this region [1]."

A lack of effective governance mechanisms has been identified as a high-priority area that needs major attention. Pressing issues regarding royalty allocation have been highlighted by the local government and community members [1]. The local government strongly stated that certain mechanisms in place to try to foster sustainable community development were weakened by the changes in the mining royalty system [34]. To what extent the current governance environment at the local level has not been beneficial for artisanal miners, their families and local stakeholders was a persistent issue brought up at the local level.

In conversations with the mayor, he stated that the lack of community development is due to the decision made at the national government to reduce mining royalties for local governments. Before 2011, local royalties would go directly to mining municipalities where minerals were produced, but recently the national government centralized the royalties and municipalities have to apply for projects related to mining activities. Funding is disbursed to execute projects that drive sustainable community development and therefore mining revenues will be allocated appropriately and in alignment with local development aspirations. However, field observations and focus groups with local communities showed this is not the case. Surprisingly, since 2011, the year in which the new royalty system was issued, Muzo has submitted only one project, which had not been implemented yet [34]. It was also found that the local government has not been able to execute past projects. Neither local government officials were able to provide us with current royalty allocation reports accounting for the execution of past and current development projects.

"In the past, $100 \%$ of mining royalties were allocated to Muzo. Now with the new royalty system Muzo receives only between 20 and $30 \%$ of mining royalties. This money has been invested mainly in projects in potable water, education and health. Muzo is a producer area that deserves to have $100 \%$ of mining revenues and royalties. We disagree with the new system and decision made on the new royalty allocation system [34]."

Previous research in the Colombian context shows that the new royalty system has elicited different reactions at the three levels of governance. While local governments complain about the significant reduction of mining revenues, the actors at the national level agree that the new system mitigates royalty allocation issues associated with poor local government managerial capacity, corruption and lack technical capacity at the local level. The regional level of governance has a neutral position in this regard [6].

Major discomfort at the community level had to do with the arrival of an American mining company in Muzo. The company acquired the concession of some of the best mining areas. It brought peace as the property rights were cleared reducing disputes of mining rights and the company fenced off its concessions, increasing security. The company also modernized mining processes investing in 
mining technology, health, safety and environment management, including actions in corporate social responsibility (CSR). However, open-access artisanal mining was the only livelihood option for most of the individual miners. Even though some of the artisanal miners found jobs in the mines controlled by the company, many could not be employed by the large company. According to community perceptions, artisanal mining has been displaced vertiginously by large-scale emerald-mining projects [1]. During the workshop, participants highlighted five dimensions in the SWOT, namely human, community/local, natural, economic and infrastructure (Table 1). Communities stated persistently that there is "peace with hunger"-participants insisted throughout the workshop that the loss of livelihood options in a peaceful environment is creating unrest among community members.

Table 1. Findings of Focus Group Discussion at the Local Level of Governance.

\begin{tabular}{|c|c|c|}
\hline Dimensions & Strengths and Opportunities & Weaknesses and Threats \\
\hline Human & 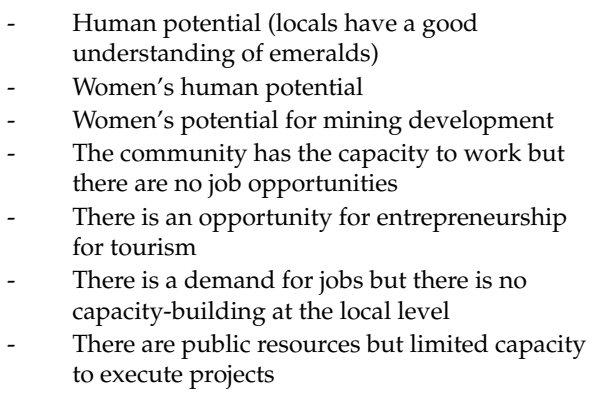 & $\begin{array}{ll}\text { - } & \text { Lack of employment } \\
\text { - } & \text { Precarious health system } \\
\text { - } & \text { Lack of capacity-building on entrepreneurship } \\
\text { - } & \text { Lack of local capacity for mining development } \\
\text { - } & \text { Unemployment }\end{array}$ \\
\hline Community/Local & $\begin{array}{l}\text { - } \quad \text { Muzo, the World Emerald Capital } \\
\text { - } \quad \text { Government support for sustainable projects }\end{array}$ & $\begin{array}{ll}\text { - } & \text { Passive role of the government, both at the } \\
\text { - } & \text { Low community participation } \\
\text { - } & \text { Lack of support for women and single mothers } \\
\text { - } & \text { Lack of communication channels } \\
\text { - } & \text { Poor corporate social responsibility practices } \\
\text { - } & \text { Locals have been excluded in recent large scale } \\
\text { mining developments } \\
\text { - }\end{array}$ \\
\hline Natural & $\begin{array}{ll}\text { - } & \text { Emeralds available } \\
\text { - } & \text { Water, land and forests }\end{array}$ & $\begin{array}{ll}\text { - } & \text { Non-renewable resources } \\
\text { - } & \text { Lack of clean water streams }\end{array}$ \\
\hline Economic & $\begin{array}{ll}\text { - } & \text { Potential for agriculture } \\
\text { - } & \text { Opportunities for tourism } \\
\text { - } & \text { There is potential for tourism } \\
\text { Development of mining, tourism and } \\
\text { - }\end{array} \quad \begin{array}{l}\text { Ogriculture supply chains } \\
\text { Opportunities for social investment }\end{array}$ & $\begin{array}{l}\text { - } \quad \text { Lack of support for local mining } \\
\text { - } \quad \text { Loss of traditional livelihood options such } \\
\text { as mining } \\
\text { - } \quad \text { Mining dependency } \\
\text { - } \quad \text { The emerald market is located outside Muzo }\end{array}$ \\
\hline Infrastructure & $\mathrm{N} / \mathrm{A}$ & Roads in poor condition \\
\hline
\end{tabular}

The discussion showed that lack of trust, credibility and communication have undermined the current governance environment. It was found there is weak institutional governance at the local level to listen to the voices of local stakeholders, as well as lack of capacity and resources in the local government. The local government has not been able to provide locals with basic public services. Health, education and infrastructure remain pressing challenges at the local level. Major discomfort is also mainly due to the lack of job opportunities. In this regard a representative of the local government states: 
"There is insufficient communication between us and the American mining company operating in Muzo. But we have managed to brainstorm some ideas and somehow collaborate for key initiatives in alignment with their social responsibility agenda. The local government has also encouraged the private sector to align with the local development plan. Otherwise, we will end up embarking on programs irrelevant for us. We hope the company helps us to provide locals with potable water. This is a huge challenge. We are also thinking of developing a tourism plan in collaboration with the American mining company. We want tourists to be able to access large mine sites and get a better understanding of emerald mining. Third, we are aiming at diversifying the economy through agriculture. However, we are very upset about this initiative because, the private company is not targeting communities adjacent to the mine site [34]."

With the arrival of the American mining company, artisanal mining communities are losing their only livelihood option gradually, but not being able to transition to other jobs. Tourism and agriculture have been identified as economic drivers; however, most of the artisanal miners have no other skills and there is no real commitment from the private sector or resources from the local government to move economic diversification forward. High dependency on mining for a long time and the unexpected arrival of the American mining company after Don Victor Carranza's death left locals with limited time to plan for alternative livelihood options, a situation that is currently threatening sustainable community development.

Once the discussion ended, we agreed with participants to conduct some field research in the coming days to validate their perceptions at the focus group discussion. Early in the morning, we visited Minero River, where we had informal conversations with some "guaqueros", another colloquial name for emerald artisanal miners. The guaqueros helped us understand past conflict dynamics and how they have impacted on community development and livelihoods.

The conflict in Muzo was labeled the "Green War" and took place in Minero River and surroundings under Don Victor Carranza's leadership. His success and wealth were mainly due to an informal governance structure he built during the Green War. In partnership with "Los Patrones and Los Duros" his most trusted friends and colleagues accountable for looking after his business, Don Victor Carranza was able to build the largest emerald empire in Colombia. Los Duros had their own "secret agents" called "the birds", covered agents for Don Victor Carranza. When someone was found with a non-reported emerald of value, the birds alerted Don Victor Carranza, who sent Los Duros to give "a lesson" to those found "guilty" (of disloyalty). Selected gemstones were given to Don Victor Carranza. Anything of value should be given to him to be sold in Bogota's black market. Those who refused to sell anything of value or crossed the line according to Don Victor Carranza's criteria were killed. Thousands of bodies were found killed at Minero River. Informal conversations with miners recalled stories of people swallowing emeralds to hide them from Los Duros. Unfortunately, people were often caught. Every single emerald should be found, even if it was swallowed by miners. Thousands of people were killed, kidnapped and disappeared during the Green War.

Guaqueros and "barequeros", or artisanal miners, were actively involved in the "voladoras" an informal mining practice allowed by Don Victor Carranza to keep the good faith with artisanal miners, in which miners scavenged the remaining debris from emerald extraction. After Don Victor Carranza's close workers had selected the best gemstones, residual ore deposits were thrown away at Minero River. This was a form of corporate philanthropy. Thousands of guaqueros and barequeros, originally from Muzo and surrounding regions, waited for days for the voladoras to occur. When they happened miners threw themselves into the Minero River to find "that" gemstone that was going to free them from poverty. Several guaqueros and barequeros were killed due to asphyxia or drowned in the Minero River. There was also conflict among artisanal miners for the sake for finding good stones. With the death of Don Victor Carranza and the arrival of the large-scale mining company, the voladoras were halted and the guaqueo informal mining practice declined notoriously, leading to unemployment and loss of income and livelihood options. 
Once the field visit was finished at Minero River the research team headed to Mina Real, a local small-scale mine. On their way to the mine site, the research team stopped at "La Playa", where emeralds have been traded informally over the years. Emerald trade in Muzo has also declined noticeably, locals stated. Due to the decline of artisanal and small-scale mining, Mina Real has embarked in a tourism project as part of their social responsibility agenda. There was a strong female presence in both administration and mining operations roles. Miners at Mina Real still perform an artisanal mining practice called "rebusque". Individual miners or groups in agreement with the company are allowed to collect emeralds from the ore they mine, generating extra income for their families. This practice is not permitted at the multinational company operating in Muzo, another issue that is creating tensions at the local level.

After the visit at Mina Real, the research team visited the largest mine site in Muzo, owned by an American company. Once at the mine, researchers proceeded to conduct interviews with representatives from environment, social responsibility, production and certification offices. It was found that security levels at the mine site were incredibly high. The research team was informed that artisanal miners have built tunnels to reach the mine site and get residual deposits illegally. There are video cameras and trained security guards everywhere at the site. Geologists and trained miners who extract the ore are accompanied by "veedores" at all times to make sure that valuable emeralds are deposited in sealed bags taken later to the CEO's office. There are also cameras filming all mining process led by a geologist. The remaining material is washed and then checked mainly by women to make sure there are no emeralds of value. The waste is deposited in safe places beyond the reach of guaqueros or informal miners to avoid the voladoras, whose material is now washed out by water jets through conveyors and the stones picked by collectors (who are former artisanal miners). The waste material is stored in a proper place inside the company area.

After finishing the field visit at the American mining company, the research team visited the property of Don Victor Carranza and talked to Don Chivitas, Don Victor Carranza's reliable chef for years. At the "Muro de los Lamentos" a stone chair where Don Victor Carranza used to perform his philanthropic endeavors, the researchers heard first-hand stories about how Don Victor Carranza was able to create the emerald empire now owned by the multinational mining company. Locals remember Don Victor Carranza with respect and admiration. There was war with no hunger and it seems locals value this more than a peaceful environment without jobs.

On the researchers' way back to Bogota, the message that resonated persistently in the researchers' minds was "peace with hunger". The research team communicated this in the second focus group discussion held in Bogota. Participants involved representatives at the regional and national levels of governance (government, private companies, academia and civil society representatives). The discussion was divided in two parts. In the first part of the findings at the community level were shared. Later, stakeholder discussion took place to identify existing community assets and priority areas for sustainable community development.

\subsection{Perceptions at the Regional and National Levels of Governance}

Surprisingly, there was an active participation of stakeholders at the highest level (for example, one director of the large company and one director of the Ministry of Mines), mostly from national level of governance, showing a high demand for such discussions. It was interesting to witness during workshops and focus groups how civil society organizations collaborated with business and government representatives as part of this exercise. The discussion focused mainly on existing priority areas at the community and government levels identified at the workshops. Evidence shows it is important that all relevant stakeholders take part in the implementation initiatives to address the identified government and community priority areas, so that they can create shared value, hopefully for all parties. However, these initiatives need to be planned carefully as locals feel these actions fail to tackle pressing issues, a situation that is also creating tension at the community level: 
"Universities and government organizations have come here to provide us with capacity-building. But you know what they do. They get our signatures to show they did the job and get credit at our expense. We need something of value in Muzo. For example, productive projects that target single mothers, widows and the elderly" [1].

Interestingly, corporate representatives state they have delivered capacity-building programs for widows and single mothers in Muzo [35]. This shows poor communication between the company and the community to address priority areas valuable for locals. Table 2 shows during the SWOT analysis how participants identified the issues in the human, community/local, natural, economic and infrastructure dimensions.

Table 2. Findings from Focus Group Discussion at the national and regional levels of governance.

\begin{tabular}{|c|c|c|}
\hline Dimensions & Strengths and Opportunities & Weaknesses and Threats \\
\hline Human & $\begin{array}{ll}\text { - } & \text { Available human capital } \\
\text { - } & \text { Cultural heritage } \\
\text { - } & \text { Other economic sector such as tourism } \\
\text { and handicrafts } \\
\text { - } & \text { Formal employment } \\
\text { - } & \text { Emerging entrepreneurs }\end{array}$ & $\begin{array}{ll}- & \text { Ineffective training } \\
- & \text { Lack of capacity-building for jewelers } \\
- & \text { Low literacy } \\
- & \text { Vocational and formal education } \\
- & \text { Entrepreneurs in rural mining areas } \\
- & \text { Lack of management skills for } \\
- & \text { productive projects } \\
- & \text { Lack of skills for royalty allocation } \\
- & \text { Unemployment due to violence }\end{array}$ \\
\hline Community/Local & $\mathrm{N} / \mathrm{A}$ & $\begin{array}{ll}- & \text { Self-interest culture } \\
- & \text { Informal mining } \\
- & \text { Lack of environmental culture } \\
- & \text { Violence } \\
- & \text { Cultural unawareness } \\
- & \text { Corruption } \\
- & \text { Legislation } \\
- & \text { Weak role of the government } \\
- & \text { Lack of equality } \\
- & \text { Social conflict } \\
- & \text { Legal uncertainty } \\
- & \text { Informal mining }\end{array}$ \\
\hline Natural & $\begin{array}{ll}\text { - } & \text { Natural resources (renewables } \\
\text { and non-renewables) } \\
\text { - } & \text { Strategic geographic location } \\
\text { - } & \text { Geological potential } \\
\text { - } & \text { Water streams }\end{array}$ & \\
\hline Economic & 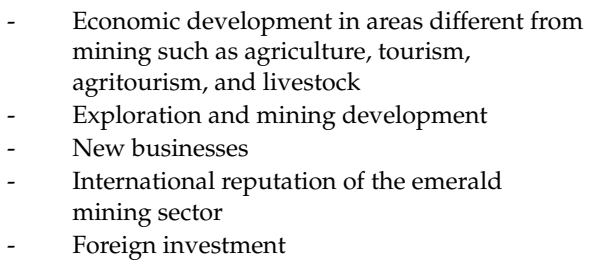 & $\begin{array}{ll}\text { - } & \text { Lack of organization among productive sectors } \\
\text { - } & \text { Lack of technical assistance for } \\
\text { industrial agriculture } \\
\text { - } \quad \text { Economic diversification and production } \\
\text { supply chains } \\
\text { - } \quad \text { Non-renewable resources } \\
\text { - } \quad \text { Environmental and social impacts }\end{array}$ \\
\hline Infrastructure & $\mathrm{N} / \mathrm{A}$ & - $\quad$ Lack of roads and public infrastructure \\
\hline
\end{tabular}

Findings show that capacity needs to be built mainly on human and community/local dimensions. According to stakeholders' perceptions at the national and regional levels of governance, local mining communities are not equipped with the technical skills to engage with mining or other industries relevant for the local economy. However, at the local level, we found contradictory statements. On the one hand, locals argue they hold the necessary skills to embark in mining. Emerald mining is the only livelihood option they have had in years and they resist being taught something they strongly believe they are qualified at. On the other hand, they do agree with the regional and national levels of governance that miners need to build their skills to forge alternative livelihood options in tourism 
and agriculture. Capacity-building in entrepreneurship has also been identified as a priority area at the local level [1]. Findings show that lack of skills and education at the community and government levels are jeopardizing stakeholders' ability to foster sustainable community development. Therefore, skills need to be built on alternative livelihood options across the mining supply chain.

We focus on key stakeholders in the mining supply chain, particularly for barequeros. They are protected by law and should have a special treatment. Unfortunately, at the national level of governance, they have been forgotten, losing their only livelihood option. Other key stakeholders in the supply chain are local traders. However, the national government has not built capacity on them, so they can engage in sustainable supply practices [34].

Findings from interviews also demonstrate there are dissimilar perceptions regarding the financial domain. At the regional and national levels of governance, stakeholders perceive this as an opportunity rather than a threat. It was stated that existing foreign investment and international reputation of the emerald-mining sector can promote sustainable community development. However, locals have divergent perceptions. There is a high dependency on artisanal mining, as most miners cannot have similar income with other activities and are not qualified to work in a large mine [36]. They are aware of existing mining potential but they feel they have not been adequately compensated. Furthermore, emerald trade is located outside Muzo, leaving locals with limited or no gains coming from mining revenue:

"Some projects have been approved under the new royalty system. However, existing governance arrangement to access resources coming from mining revenues are difficult to access. When financial resources are allocated at the local level, they have already passed through so many hands that we got nothing at the end. We have proposed projects but usually our proposals have been thrown away. There is not an effective allocation of those resources" [1].

It was also identified that conflict has had adverse implications for Muzo's social tissue. It will take time for mining communities to rebuild social cohesion in a postconflict stage. Stakeholders at all levels of governance agree there is lack of trust, communication, credibility, community participation in decision-making and equality. These issues derived from conflict are also reflected in corruption, illegal economic activities and poor governance. Institutional capacity to face these challenges in a postconflict scenario is pivotal to foster inclusive, sustainable development at the local level.

\subsection{Collaborative Governance Approach to Sustainable Community Development in Resource Regions}

Fostering sustainable community development in line with global demands is the responsibility of all parties involved. It also requires increased awareness of the complexity of collaborative governance arrangements and embracing divergent perceptions, particularly those coming from communities' and stakeholders' perceptions. Based on research findings, this study proposes a multi-level collaborative governance approach to sustainable community development. This approach consists of previously discussed stakeholders' perceptions at all levels of governance about community assets and priority areas for sustainable community development. This approach has the potential to be applied to other resource regions in Colombia or elsewhere (See Figure 1).

Research found that collaborative governance should focus on five priority assets, namely social, human, financial, natural and physical. Stakeholders at all level of governance also identified main areas that need to be paid major attention to enhance their assets. These were clustered by stakeholders according the abovementioned assets. A real commitment from stakeholders in these assets and priority areas can contribute to sustainable community development in the context of resource regions. Years of conflict and the arrival of international investment have impacted social tissue and governance systems. Findings showed that social assets need major attention. It also demonstrated there is a need to build the social tissue and strengthen governance mechanisms. In addition, support for women and stronger community participation are two key issues that need to be addressed by all parties involved. Background research in the Colombian case had already documented this gender issue [6]. Women are 
very often the most vulnerable actors in mining regions of Colombia. Lack of education and gainful employment opportunities exacerbates their condition. The Muzo region, for example, is populated by widows whose husbands were killed during the Green War. These women still struggle to sustain their families in a decent manner compared to other Colombian mining regions, where women do not have other options than choosing prostitution as a livelihood option [6]. In response, the mining company operating in Muzo has embarked on corporate social responsibility to address this issue [35]. Despite that, no positive outcomes have been unveiled due to the dimension and complexity of the problem.

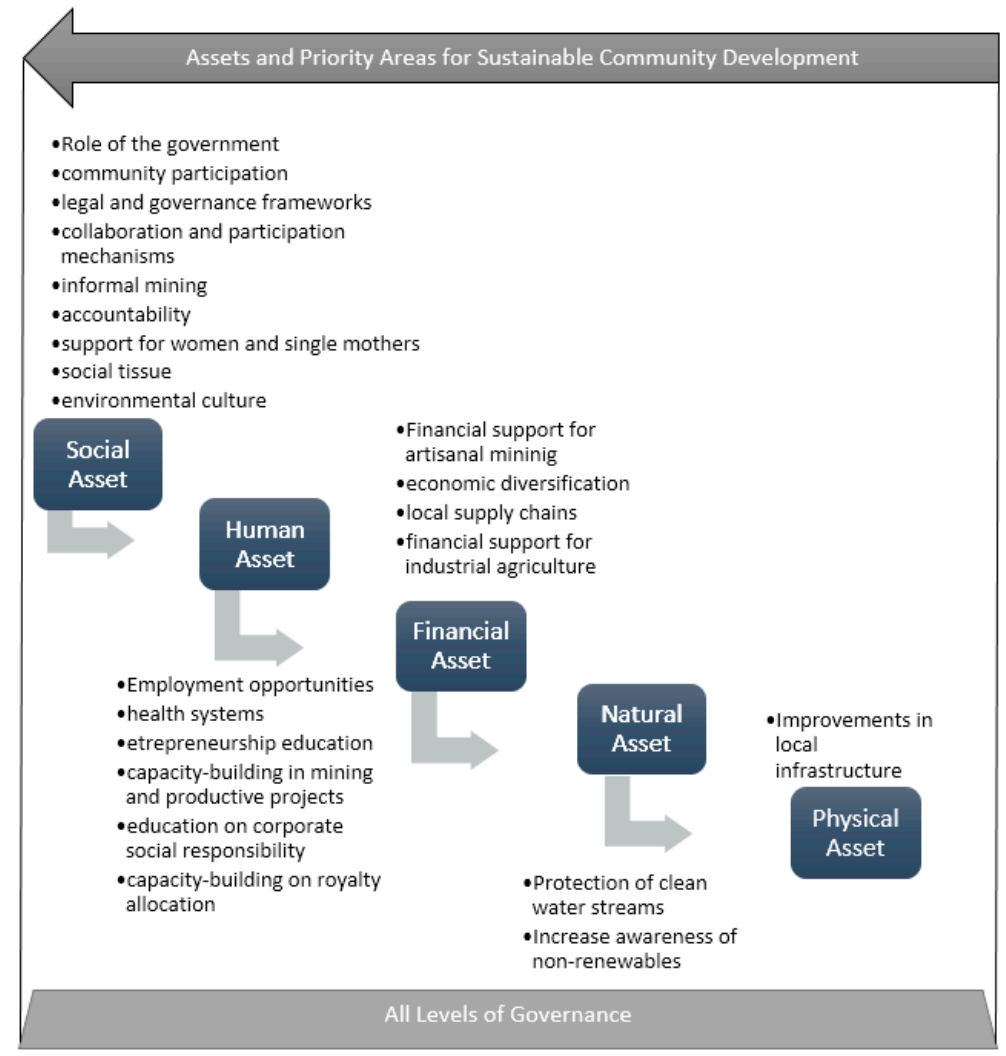

Figure 1. Collaborative Governance Approach to Sustainable Community Development in Resource regions.

Evidence also shows that rebuilding the social issue needs to be accompanied by capacity-building for human capital development in which education plays a key role. Capacity-building for stakeholders on royalty allocation and corporate social responsibility are key to allocating mining revenues effectively and in a transparent manner. Similarly, education for sustainable livelihoods in mining and productive projects has been identified as priority areas. Participants argued capacity-building in these areas should also be delivered along with financial support for economic diversification projects. Interestingly, less attention is being paid to natural and physical assets.

\section{Conclusions and Recommendations}

Although this research focused on Colombia, the conclusions are highly likely to be applicable to other resource locations in developing countries in Latin America and elsewhere, given the structural similarities that are evident in resource-dependent rural communities [37]. This research showed there is potential for sustainable emerald-mining development if stakeholders acknowledge the complexity in their relationships and collaborate to address pressing governance issues at the local level. On the contrary, stakeholders in Colombia will continue experiencing significant challenges to foster sustainability community development. This investigation also increases our understanding of 
community assets and priority areas for sustainable community development on artisanal emerald and draws recommendations for better governance in this regard. Specific conclusions derived from this research have to do with assets and priority areas identified by stakeholders. A general conclusion derived from this study reveals that due to past conflict implications for locals, "peace with hunger" will remain unless community assets are realized and targeted seriously by all parties involved. Thus, based on research results this study recommends stakeholders target community assets listed below:

Social Assets: Improvements in collaborative governance arrangements with regards to mining formalization, stronger social and environmental policies, royalty allocation, tax collection and strengthening of the social tissue. These areas are pivotal to help communities protect their social assets.

Human Assets: collaboration between artisanal miners and large-scale mining companies, for human capital capacity-building, for artisanal miners and their families, is key to foster sustainable community development.

Financial Assets: Improvements in emerald-mining production and commercialization across the supply chain. Participants identified that major support to livelihoods in mining and other productive projects could assist them to enhance their financial assets.

Natural Assets: End of informal mining and the beginning of an emerging formalized and modern emerald-mining sector. With the arrival of global international companies, more awareness of non-renewables and protection of water streams are two areas that need to be enhanced to protect natural assets at the local level.

Physical Assets: Stakeholders should also aim to protect physical assets. Although this was considered by participants to be a low-priority area, investments in public infrastructure such as roads can boost the local economy.

Evidently a general conclusion form this study has to do with past conflict dynamics driven by illegitimate actors who have impacted on community assets. Local communities have not been able to meet their own development aspirations in various areas. Yet, the issues remained after the conflict and have been aggravated with the arrival of the American mining company. The private sector and government authorities are reluctant to engage with artisanal miners in Muzo due to their suspicions of links between the community and illegal groups. This has not only exacerbated discontent, but has also resulted in the ongoing destruction of livelihoods in artisanal mining, a situation that limits the opportunities to fight "hunger with peace" and foster overall sustainability.

This research recommends stakeholders target priority assets during the peace-building phase for effective and sustainable community development. Addressing these priority areas may assist stakeholders in helping communities to move forward to fight hunger with peace. Evidence showed that factors such as inequitable distribution of mining revenues along with the loss of mining as a livelihood option are exacerbating discontent and threatening community assets following peace. This investigation also showed inclusive relevant sustainable development has been hampered by the arrival of multinational companies, a weak social tissue due to past conflict dynamics and lack of human capital. Therefore, there are some priority areas that need to be addressed by hopefully all stakeholders involved. Findings demonstrated that mining communities in Muzo, Colombia have been inadequately compensated by the changes in the processes of resource extraction after peace. Poor governance, lack of capacity for royalty allocation and provision of public services have led to social unrest. Lack of formalization of artisanal mining activities has also exacerbated the issue. Mining economic benefits have favored only a few segments of the community, threatening overall sustainability. This, in turn, has led to unemployment, reduction in local wealth and lack of opportunities for economic diversification.

Based on key findings, this investigation identified opportunities such as active stakeholder engagement for sustainable community development. These public and private coalitions have the potential to foster community capacity-building to enhance community assets in priority areas such as economic diversification and alternative livelihood options. Preliminary capacity-building in key sectors for the local economy, such as agriculture and tourism, has been undertaken in collaboration 
with the stakeholders involved. However, greater investment in these areas is highly recommended. Likewise, stronger institutional capacity at the local level will foster the creation of participatory governance mechanisms for more equitable mining revenue distribution. This will hopefully enable stakeholders to collaborate to fight hunger with the prevalence of peace and fostering sustainable community development in emerald-mining regions of Colombia and elsewhere.

Author Contributions: The reported research is the result of collaborative work. The first draft was developed by Isabel B. Franco with contributions subsequently from the other two authors. Saleem H. Ali contributed substantially in the research design of the study and developing the conceptual narrative of the article. Jose A. Puppim de Oliveira and Isabel B. Franco conducted field research and analyzed data. All authors read and approved the final manuscript.

Conflicts of Interest: We declare no conflict of interest.

\section{References}

1. Community Members. Local Level of Governance; Focus Group Discussion: Muzo, Colombia, 2017.

2. Davies, J.S. Local Governance and the Dialectics of Hierarchy, Market and Network. Policy Stud. 2005, 26, 311-335. [CrossRef]

3. World Food Program (WFP). Fighting Hunger with Peace. 2017. Available online: https://www.wfp.org/ stories / fighting-hunger-peace (accessed on 12 December 2017).

4. Kwarteng, K. War and Gold: A Five-Hundred-Year History of Empires, Adventures, and Debt, 1st ed.; PublicAffairs: New York, NY, USA, 2014.

5. Morris, I. War! What Is It Good For?: Conflict and the Progress of Civilization from Primates to Robots; Farrar, Straus and Giroux: New York, NY, USA, 2014.

6. Franco, I.B. Building Sustainable Communities: Enhancing Human Capital in Resource Regions. Ph.D. Thesis, The University of Queensland, Brisbane, Australia, 2014.

7. Franco, I.; Ali, S. Decentralization, Corporate Community Development and Resource Governance: A Comparative Analysis of Two Mining Regions in Colombia. Extr. Ind. Soc. 2016, 4, 111-119. [CrossRef]

8. Minnery, J. Stars and their Supporting Cast: State, Market and Community as Actors in Urban Governance. Urban Policy Res. 2007, 25, 325-345. [CrossRef]

9. Alizar, A.; Scott, R. Working at the Local Level to Support Sustainable Mining. Can. Min. J. 2009, 130, $24-25$.

10. Muthuri, J.N. Corporate Citizenship and Sustainable Development-Fostering Multi-Sector Collaboration in Kenya. J. Corp. Citizensh. 2007, 28, 73-84. [CrossRef]

11. Warhust, A. Corporate Citizenship and Corporate Social Investment. J. Corp. Citizensh. 2001, 2001, 57-73. [CrossRef]

12. International Council on Mining and Metals (ICMM). Community Development Toolkit. 2005. Available online: https:/ / www.icmm.com/news-and-events/news/articles/icmm-presents-updated-communitydevelopment-toolkit (accessed on 12 December 2017).

13. Bond, C.J. Positive peace and sustainability in the mining context: Beyond the triple bottom line. J. Clean. Prod. 2014, 84, 164-173. [CrossRef]

14. Himley, M. Global mining and the uneasy neoliberalization of sustainable development. Sustainability 2010, 2, 3270-3290. [CrossRef]

15. Wang, L.; Awuah-Offei, K.; Que, S.; Yang, W. Eliciting Drivers of Community Perceptions of Mining Projects through Effective Community Engagement. Sustainability 2016, 8, 658. [CrossRef]

16. Bond, C.; Everingham, J.A.; Franks, D. Managing the Cumulative Impacts of Mining through Collaboration: The Moranbah Cumulative Impacts Group (MCIG); The University of Queensland: Brisbane, Australia, 2013.

17. International Council on Mining and Metals (ICMM). 10 Principles. 2003. Available online: http://www. icmm.com/our-work/sustainable-development-framework/10-principles (accessed on 12 December 2017).

18. Liu, Q.; Yang, Z.; Wang, F. Conservation Policy-Community Conflicts: A Case Study from Bogda Nature Reserve, China. Sustainability 2017, 9, 1291. [CrossRef]

19. Mate, K. Capacity-Building and Policy for Sustainable Development Networking. Miner. Energy Raw Mater. Rep. 2001, 16, 3-25. [CrossRef] 
20. Institute for Environment and Development (IED). Building Partnerships: Key Elements of Capacity Building; An Exploration of Experiences with Mining Communities in America Latina; Mining, Minerals and Sustainable Development; International Institute for Environmental Development: London, UK, 2001; Volume 33.

21. Asamoah, E.F.; Zhang, L.; Liang, S.; Pang, M.; Tang, S. Emergy Perspectives on the Environmental Performance and Sustainability of Small-Scale Gold Production Systems in Ghana. Sustainability 2017, 9, 2034. [CrossRef]

22. Veiga, M.; Scoble, M.; McAllister, M.L. Mining with Communities. Nat. Resour. Forum 2001, 25, $191-202$. [CrossRef]

23. Lahiri-Dutt, K.; Slack, K.; Secretariat of the IGCP Programme; Baker, L.; Downs, T.J.; MaNeely, J.A.; Tambunan, T.; Iftekhar, M.S.; Franks, D.; Souza, W.; et al. How Can Revenues from Natural Resources Extraction Be More Efficiently Utilized for Local Sustainable Development? Nat. Resour. Forum 2009, 33, 245-249. [CrossRef]

24. Lanzi, D. Capabilities, Human Capital and Education. J. Socio-Econ. 2007, 36, 424-435. [CrossRef]

25. Bridge, G. Harnessing the Bonanza: Economic Liberalization and Capacity Building in the Mineral Sector. Nat. Resour. Forum 1999, 23, 43-55. [CrossRef]

26. Milanez, B.; de Oliveira, J.A.P. Innovation for sustainable development in artisanal mining: Advances in a cluster of opal mining in Brazil. Resour. Policy 2013, 38, 427-434. [CrossRef]

27. De Oliveira, J.A.P.; Ali, S.H. Gemstone mining as a development cluster: A study of Brazil's emerald mines. Resour. Policy 2011, 36, 132-141. [CrossRef]

28. Torres, I. The Mineral Industry of Colombia. 2001. Available online: http://minerals.usgs.gov/minerals / pubs/country/2001/comyb01r.pdf (accessed on 12 December 2017).

29. De la Hoz, J.V. Cerro Matoso y la Economía del Ferroníquel en el Alto San Jorge (Córdoba). Econ. Soc. 2009, 20, 41-58.

30. Ragin, C.C. What is a Case? Exploring the Foundations of Social Inquiry; Cambridge University Press: Cambridge, UK, 1992.

31. Carroll, B.W.; Carroll, T. Civic Networks, Legitimacy and the Policy Process. Governance 1999, 12, 1-28. [CrossRef]

32. Hilson, G.M. Championing the Rhetoric? "Corporate Social Responsibility" in Ghana's mining sector. Greener Manag. Int. 2006, 53, 43-56. [CrossRef]

33. Congreso de la Republica de Colombia. Constitución Política de Colombia; Congreso de la Republica de Colombia: Bogota, Colombia, 1991.

34. Government Representatives. Local Level of Governance; Focus Group Discussion: Bogota, Colombia, 2017.

35. Corporate Representatives. Focus Group Discussion; Muzo, Colombia, 2017.

36. Government Representatives. Regional and National Level of Governance; Focus Group Discussion: Bogota, Colombia, 2017.

37. Bebbington, A. (Ed.) Social Conflict, Economic Development and Extractive Industry: Evidence from South America, 1st ed.; Routledge: Abingdon, UK; New York, NY, USA, 2013.

(C) 2018 by the authors. Licensee MDPI, Basel, Switzerland. This article is an open access article distributed under the terms and conditions of the Creative Commons Attribution (CC BY) license (http://creativecommons.org/licenses/by/4.0/). 